\title{
Pengaruh Perubahan UU 32/2004 Menjadi UU 23/2014 Terhadap Luas Wilayah Bagi Hasil Kelautan Terminal Teluk Lamong antara Kota Surabaya, Kabupaten Gresik dan Kabupaten Bangkalan
}

\author{
Melisa Ayuningtyas, Khomsin \\ Jurusan Teknik Geomatika, Fakultas Teknik Sipil dan Perencanaan, Institut Teknologi Sepuluh \\ Nopember (ITS) \\ Jl. Arief Rahman Hakim, Surabaya 60111 Indonesia \\ e-mail:khomsin@geodesy.its.ac.id, melisayuningtyas@gmail.com
}

\begin{abstract}
Abstrak - Batas laut adalah suatu pembatas kewenangan pengelolaan sumber daya di laut yang berupa rangkaian titik-titik koordinat yang diukur dari garis pantai. Kewenangan untuk pengelolaan sumber daya di laut diatur oleh Undang-Undang tentang Pemerintahan Daerah, yaitu Undang-Undang Nomor 32 Tahun 2004 kemudian digantikan oleh Undang-Undang Nomor 23 Tahun 2014. Terdapat kondisi yang perlu diperhatikan saat pengukuran batas laut, yaitu posisi dari daerah yang berbatasan. Penarikan garis batas dilakukan dengan metode sama jarak (equidistance) untuk daerah yang berdampingan dan metode garis tengah (median line) untuk daerah yang berseberangan. Pada penelitian ini terdapat tiga alternatif penarikan batas terkait sengketa Pulau Galang, yaitu jika Pulau Galang dianggap tidak ada, jika masuk Kota Surabaya dan jika masuk Kabupaten Gresik. Diperoleh hasil tarikan batas yang berbeda pengaruh perubahan UU 32/2004 menjadi UU 23/2014 yang menghasilkan perubahan luas wilayah bagi hasil kelautan Terminal Teluk Lamong. Wilayah yang memperoleh bagi hasil kelautan hanya Kota Surabaya dan Kabupaten Gresik. Perubahan luas wilayah bagi hasil Terminal Teluk Lamong terbesar dari perubahan UU yaitu 26,018 Ha pada alternatif jika Pulau Galang dianggap tidak ada dan perubahan terkecil yaitu 11,291 Ha pada alternatif jika Pulau Galang masuk Kabupaten Gresik.
\end{abstract}

Kata Kunci-Bagi Hasil Kelautan, Batas Laut, UU 23/2014, UU 32/2004

\section{PENDAHULUAN}

$\mathrm{P}$ EMISAH wilayah penyelenggaraan kewenangan dari suatu daerah dengan daerah lain disebut batas daerah. Batas daerah terdiri atas batas daerah di darat dan di laut, yang bukan alokasi teritorial sehingga tidak menentukan kedaulatan. Batas daerah di laut atau batas laut adalah pembatas kewenangan pengelolaan sumber daya di laut untuk daerah bersangkutan yang merupakan rangkaian titik-titik koordinat yang diukur dari garis pantai [1]. Daerah yang memiliki wilayah laut memiliki kewenangan untuk mengelola sumber daya di wilayah lautnya yang telah diatur dalam Undang-Undang tentang Pemerintahan Daerah, yaitu Undang-Undang Nomor 32 Tahun 2004 yang kemudian digantikan dengan Undang-Undang Nomor 23
Tahun 2014.

Kewenangan mengelola sumber daya di wilayah laut untuk daerah yang memiliki wilayah laut berdasarkan UU 32/2004 adalah paling jauh 12 mil laut yang diukur dari garis pantai ke arah laut lepas dan/atau ke arah perairan kepulauan untuk wilayah provinsi dan $1 / 3$ (sepertiga) dari wilayah kewenangan provinsi adalah kewenangan kabupaten/kota. Garis pantai yang digunakan sebagai acuan pada UU 32/2004 dalam penarikan garis batas adalah perpotongan garis air rendah dengan daratan. Sedangkan jika berdasarkan UU 23/2014, batas kewenangan untuk kabupaten/kota semata-mata hanya untuk keperluan penghitungan bagi hasil kelautan yaitu sejauh 4 mil laut yang diukur dari garis pantai ke arah laut lepas dan/atau ke arah perairan kepulauan dan untuk kewenangan daerah provinsi adalah tetap sama yaitu untuk mengelola sumber daya alam di laut paling jauh 12 mil laut diukur dari garis pantai ke arah laut lepas dan/atau ke arah perairan kepulauan. Garis pantai yang digunakan sebagai acuan pada UU 23/2014 untuk penarikan garis batas adalah batas pertemuan antara bagian laut dan daratan pada saat terjadi pasang air laut tertinggi.

Terdapat banyak sumber daya alam maupun buatan pada wilayah laut perbatasan antara Kota Surabaya, Kabupaten Gresik dan Bangkalan, diantaranya Pulau Galang dan Terminal Teluk Lamong. Pulau Galang hingga saat ini pengelolaannya masih terbentur permasalahan penetapan batas wilayah antara Pemerintah Kota Surabaya dan Pemerintah Kabupaten Gresik, maka dari itu dibuatlah beberapa alternatif penarikan garis batas pada penelitian ini. Oleh karena itu, penentuan batas wilayah laut daerah sangatlah penting karena perlunya kepastian suatu posisi, eksistensi dan status hukum untuk batas itu sendiri [2]. Luas wilayah bagi hasil kelautan Terminal Teluk Lamong juga dipengaruhi oleh penentuan batas wilayah laut daerah.

\section{METODOLOGI PENELITIAN}

\section{A. Lokasi Penelitian}

Lokasi penelitian mengambil wilayah laut perbatasan antara Kota Surabaya, Kabupaten Gresik dan Kabupaten Bangkalan. Adapun batasan lokasi pada penelitian secara geografis terletak 
pada koordinat $7^{\circ} 8^{\prime} 42,308^{\prime \prime}$ LS $-7^{\circ} 14^{\prime} 11,774^{\prime \prime}$ LS dan $112^{\circ}$ $38^{\prime} 41,2^{\prime \prime}$ BT - $112^{\circ} 44^{\prime} 3,66^{\prime \prime}$ BT.

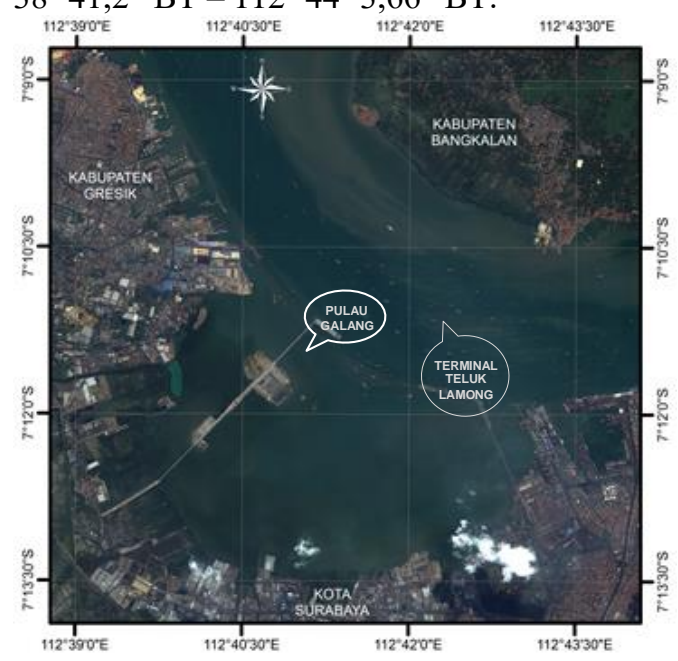

Gambar 1. Lokasi Penelitian

\section{B. Data}

Data yang digunakan dalam penelitian ini adalah:

a. Peta Lingkungan Pantai Indonesia (LPI) tahun 2002 skala 1:50.000 format (*.shp) terbitan Bakosurtanal

b. Peta Rupa Bumi Indonesia (RBI) tahun 2001 skala 1:25.000 format (*.shp) terbitan Bakosurtanal

c. Citra satelit resolusi tinggi SPOT7 tahun 2015 yang telah terkoreksi dalam format (*.ers) dari Lembaga Penerbangan dan Antariksa Nasional (LAPAN)

d. UU 32/2004 tentang Pemerintahan Daerah

e. UU 23/2014 tentang Pemerintahan Daerah

f. Permendagri 76/2012 tentang Pedoman Penegasan Batas Daerah

\section{Tahap Pengolahan Data}

Pengolahan data dimulai dengan penentuan garis pantai [3][4], kemudian dilanjutkan proses penarikan batas kewenangan kabupaten/kota, pembuatan alternatif konstruksi batas terkait sengketa Pulau Galang dan yang terakhir adalah penarikan garis batas wilayah laut daerah untuk Kota Surabaya, Kabupaten Gresik dan Bangakalan. Metode yang digunakan dalam pembuatan konstruksi batas adalah metode equidistance (sama jarak) dan metode median line (garis tengah) [5] yang disesuaikan dengan UU 32/2004 dan UU 23/2014. Hasil dari pengolahan data kemudian dianalisa sehingga diperoleh adanya selisih luas wilayah bagi hasil kelautan Terminal Teluk Lamong antara Kota Surabaya, Kabupaten Gresik dan Bangkalan.

\section{HASIL DAN ANALISA}

\section{A. Hasil Penentuan Garis Pantai}

Citra satelit resolusi tinggi SPOT-7 digunakan pada proses digitasi dalam penentuan garis pantai muka air tinggi atau High Water Level (HWL) dengan acuan yang digunakan berdasarkan UU 23/2014, karena belum adanya peraturan yang mengatur mengenai peta dasar yang digunakan sebagai acuan. Proses digitasi dilakukan dengan prinsip pendekatan, sehingga karakteristik wilayah pantai perlu diperhatikan. Pada pantai buatan, garis pantai ditentukan dari garis batas terluar suatu bangunan permanen yang terletak di pinggir pantai. Untuk wilayah pantai pepohonan, garis pantai diwakili oleh batas tumbuhan terluar yang dekat dengan daratan [6].

Sedangkan, untuk penarikan garis pantai muka air rendah atau Low Water Level (LWL) dengan acuan berdasarkan UU 32/2004 tidak dilakukan proses digitasi seperti pada saat proses digitasi HWL. Hal tersebut dikarenakan pada Peta LPI telah tersedia informasi mengenai kontur nol laut yang digunakan sebagai batas air surut terendah. Selain itu, data Peta LPI yang diperoleh pada penelitian ini sudah dalam format shapefile (*.shp).

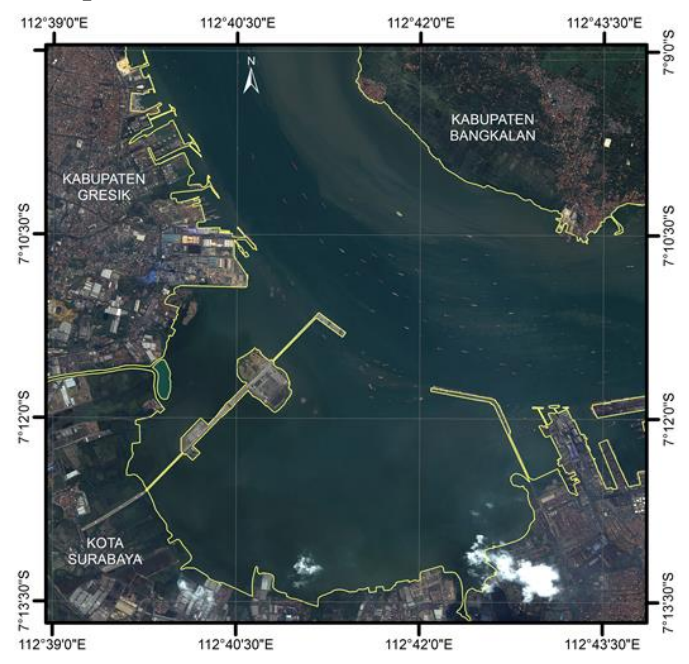

Keterangan

- Garis Panta

Gambar 2. Hasil Penentuan Garis Pantai Muka Air Tinggi (High Water Level)

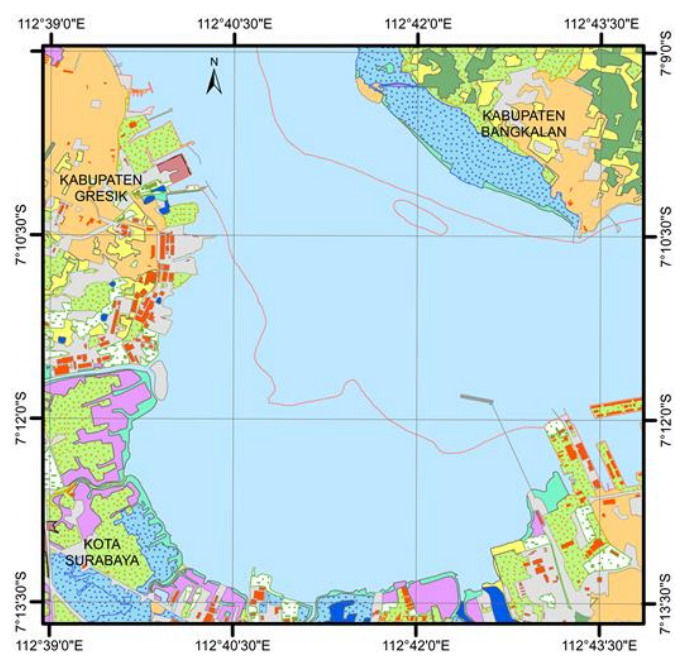

Keterangan

- Garis Panta

Gambar 3. Hasil Penentuan Garis Pantai Muka Air Rendah (Low Water Level)

\section{B. Hasil Penarikan Batas Kewenangan Kabupaten/Kota}

Kewenangan mengelola sumber daya di wilayah laut untuk daerah yang memiliki wilayah laut berdasarkan UU 32/2004 adalah paling jauh 12 mil laut yang diukur dari garis pantai ke arah laut lepas dan/atau ke arah perairan kepulauan untuk wilayah provinsi dan 1/3 (sepertiga) dari wilayah kewenangan provinsi adalah kewenangan kabupaten/kota. Garis pantai yang digunakan sebagai acuan dalam penarikan garis batas adalah perpotongan garis air rendah dengan daratan. Pulau Jawa dan Madura adalah dua daratan terpisah namun masih berada dalam satu provinsi, maka batas kewenangan provinsinya sejauh 12 
mil laut dan batas kewenangan kabupaten/kota sejauh 4 mil laut dari 1/3 (sepertiga) dari wilayah kewenangan provinsi.

Sedangkan berdasarkan UU 23/2014, batas kewenangan untuk kabupaten/kota semata-mata hanya untuk keperluan penghitungan bagi hasil kelautan yaitu sejauh 4 mil laut yang diukur dari garis pantai ke arah laut lepas dan/atau ke arah perairan kepulauan dan garis pantai yang digunakan sebagai acuan penarikan garis batas adalah batas pertemuan antara bagian laut dan daratan saat terjadi pasang air laut tertinggi.

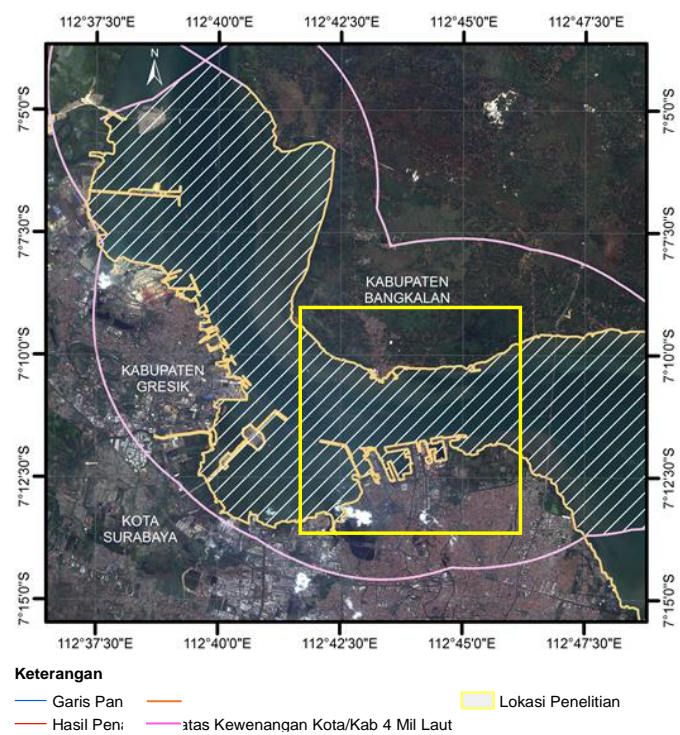

Gambar 4. Hasil Penarikan Batas Kewenangan Kabupaten/Kota pada Garis Pantai Muka Air Tinggi (High Water Level)

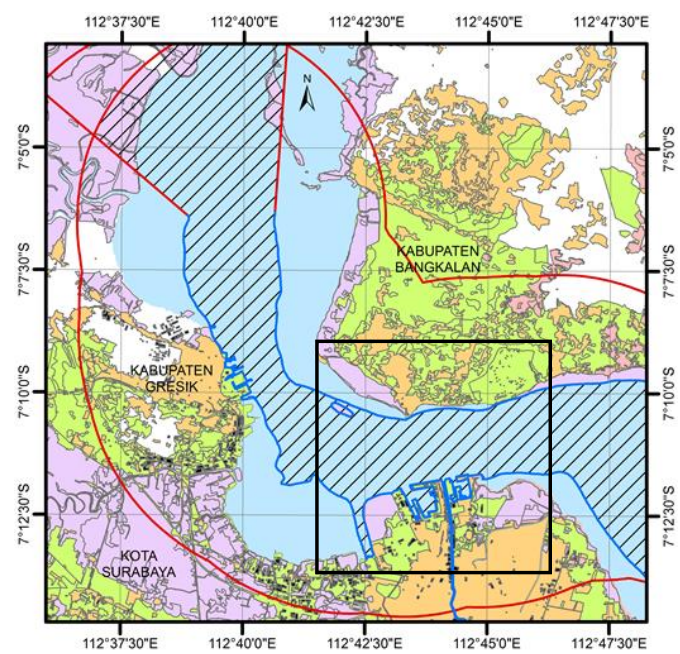

Keterangan

- Garis Panta

- Hasil Penarikan Batas Kewenangan Kota/Kab 4 Mil Laut

Lokasi Pe $\square$

Gambar 5. Hasil Penarikan Batas Kewenangan Kabupaten/Kota pada Garis Pantai Muka Air Rendah (Low Water Level)

Hasil penarikan batas kewenangan untuk Kota Surabaya dan Kabupaten Gresik sejauh 4 mil laut yang dihitung dari garis pantai LWL sesuai UU 32/2004 (Gambar 4) dan garis pantai HWL sesuai UU 23/2014 (Gambar 5) telah melebihi wilayah lautnya masing-masing hingga menyentuh wilayah daratan dari Kabupaten Bangkalan. Begitu juga untuk batas kewenangan Kabupaten Bangkalan yang hingga menyentuh wilayah daratan Kota Surabaya dan Kabupaten Gresik. Hal tersebut dikarenakan jarak antar wilayah kurang dari 4 mil laut, sehingga wilayah laut tersebut menjadi wilayah pertampalan klaim antara Kota Surabaya, Kabupaten Gresik dan Bangkalan.

\section{Hasil Pembuatan Konstruksi Batas Wilayah}

Untuk menangani pertampalan klaim yang terjadi antara Kota Surabaya, Kabupaten Gresik dan Kabupaten Bangkalan, dibuat konstruksi batas wilayah laut daerah dengan metode equidistance (sama jarak) untuk wilayah berdampingan dan metode median line (garis tengah) untuk wilayah saling berseberangan. Metode tersebut juga telah dijelaskan dalam Lampiran Permendagri Nomor 76 Tahun 2012 tentang Pedoman Penegasan Batas Daerah, yang kemudian disesuaikan dengan UU 32/2004 dan UU 23/2014.

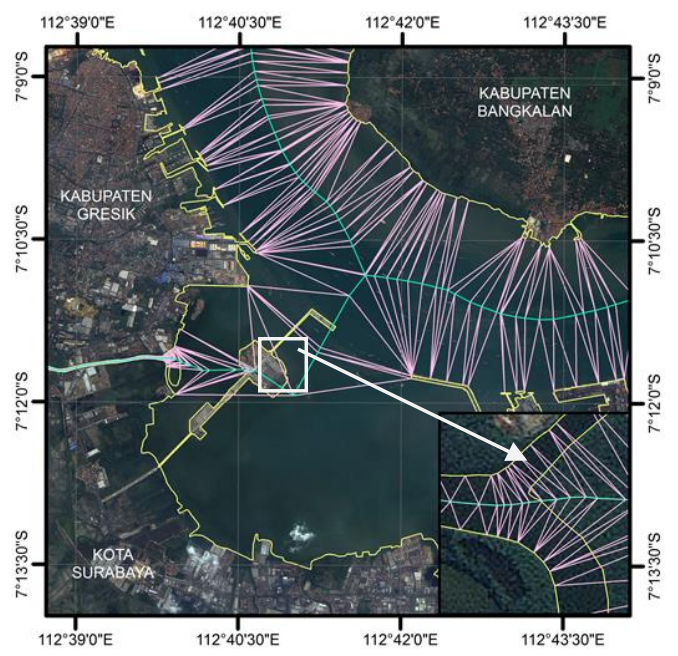

(a)

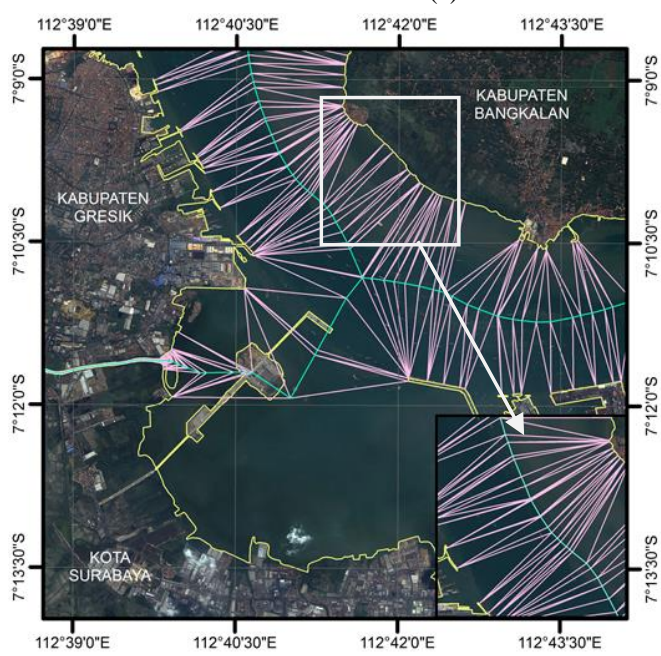

(b)

Keterangan

— Batas Wilayah Pengelola

- Konstruksi Batas Metode Garis Tengah (Median Line)

Garis Pantai

Gambar 6. Contoh Hasil Konstruksi Batas dengan Metode (a) Sama Jarak (Equidistance), (b) Garis Tengah (Median Line)

Prinsip penarikan garis batas kedua metode tersebut adalah sama yaitu dengan dengan menghubungkan 3 titik dasar pada 1 lingkaran yang menyinggung ketiga titik tersebut. Titik dasar ditentukan secara subjektif dengan jarak yang dimiliki tidak jauh satu sama lain dan merupakan titik terluar dari garis pantai, sehingga ketika dihubungkan dengan lingkaran tidak akan memotong garis pantai (wilayah daratan) terlalu banyak. Selain 
itu, sengketa Pulau Galang yang hingga saat ini masih terbentur permasalahan penetapan batas wilayah antara Pemerintah Kota Surabaya dengan Kabupaten Gresik juga harus diperhatikan, untuk itu dibuat tiga alternatif penarikan batas diantaranya jika Pulau Galang dianggap tidak ada, jika Pulau Galang masuk Kota Surabaya dan jika Pulau Galang masuk Kabupaten Gresik. Kemudian dibuat konstruksi batas wilayah laut untuk tiap alternatif terkait sengketa Pulau Galang berdasarkan masingmasing UU 32/2004 dan UU 23/2014.

Pada penelitian ini, Terminal Teluk Lamong diasumsikan tidak ada pada saat pembuatan konstruksi batas dengan acuan garis HWL (UU 23/2014) karena statusnya terbagi kedalam dua wilayah yaitu wilayah Kota Surabaya dan Kabupaten Gresik jika berdasarkan UU 32/2004. Peninjauan dilakukan berdasar UU 32/2004 karena pembangunan Terminal Teluk Lamong telah rampung sebelum UU 23/2014 disahkan.

\section{Hasil dan Analisa Bagi Hasil Kelautan}

Pada Gambar 7, terdapat wilayah yang berwarna abu-abu yaitu wilayah pertampalan klaim bagi hasil kelautan Terminal Teluk Lamong antara Kota Surabaya dan Kabupaten Gresik dari adanya perubahan UU 32/2004 menjadi UU 23/2014. Wilayah berwarna abu-abu tersebut memiliki dua penjelasan berbeda. Pertama, wilayah tersebut merupakan wilayah bagi hasil kelautan Terminal Teluk Lamong untuk Kota Surabaya yang berkurang dari adanya perubahan UU di atas. Kedua, wilayah tersebut merupakan wilayah bagi hasil kelautan Terminal Teluk Lamong untuk Kabupaten Gresik yang bertambah dari adanya perubahan UU di atas.

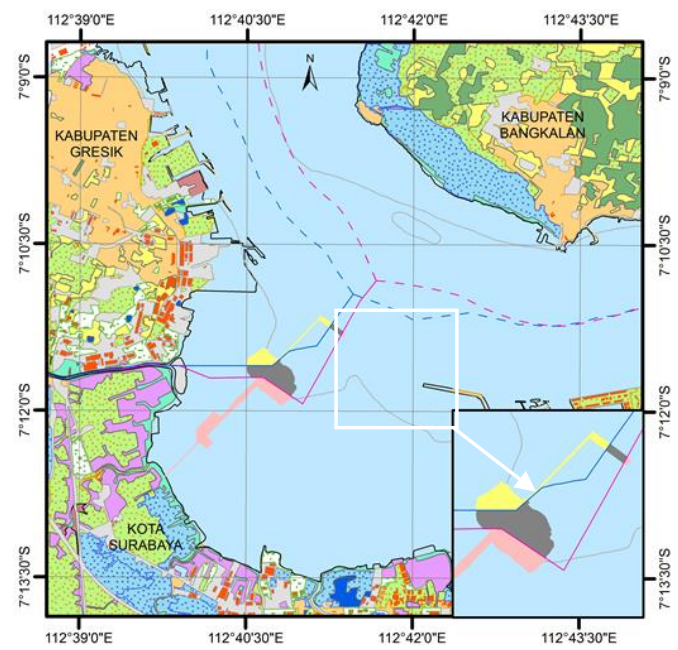

(a)

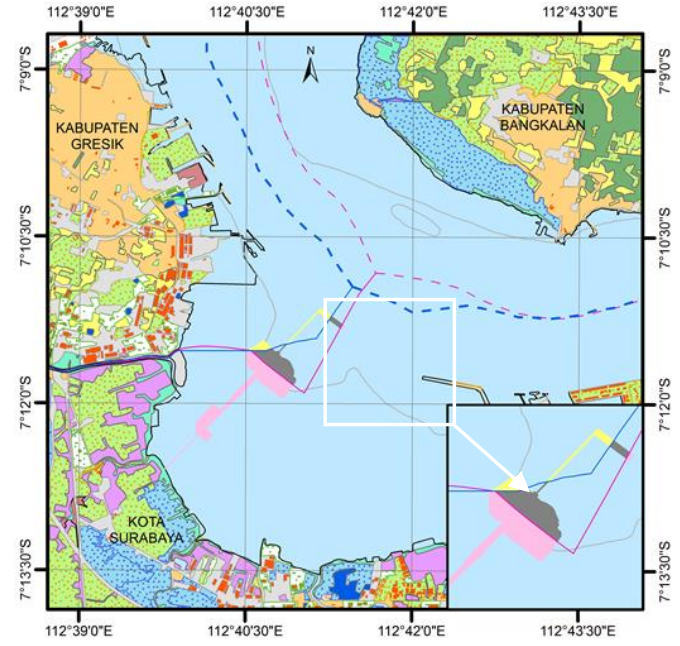

(b)

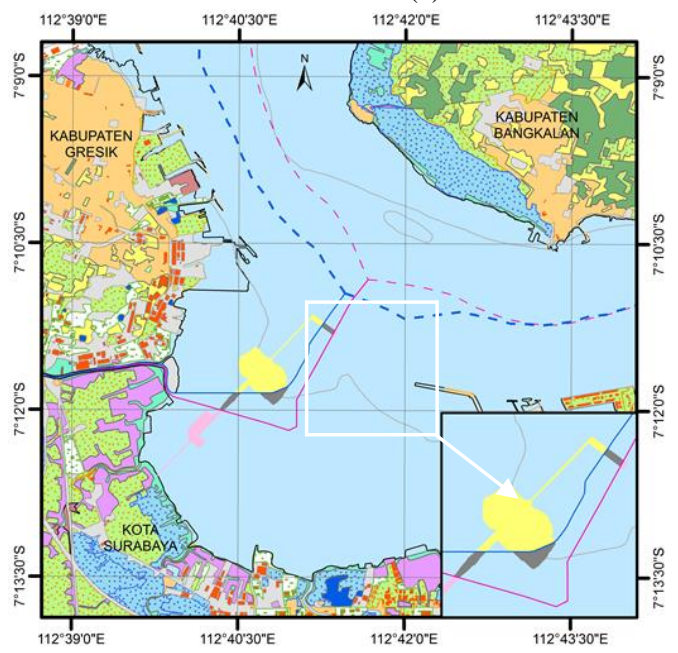

(c)

Keterangan

- Batas Berdasar UU 32/2004 (Equidistance)

- Batas Berdasar UU 32/2004 (Equidistance)

- Batas Berdasar UU 32/2004 (Median Line)

Wil. Terminal Teluk Lamong masuk Kab. Gresik (UU 32/2004) Wil. Terminal Teluk Lamong masuk Kota Surabaya (UU 23/2014) Wilayah Pertampalan Klaim Bagi Hasil Kelautan - Garis Pantai Low Water Level (LWL)

Gambar 7. Alternatif Luas Wilayah Bagi Hasil Kelautan Terminal Teluk Lamong antara Kota Surabaya, Kabupaten Gresik dan Kabupaten Bangkalan (a) Jika Pulau Galang Dianggap Tidak Ada, (b) Jika Pulau Galang Masuk Kota Surabaya, (c) Jika Pulau Galang Masuk Kabupaten Gresik

Adapun luas wilayah bagi hasil kelautan Terminal Teluk Lamong untuk tiap wilayah di tiap alternatif terkait sengketa Pulau Galang dijelaskan pada Tabel 1 berikut ini.

Tabel 1.

Luas Wilayah Bagi Hasil Kelautan Terminal Teluk Lamong antara Kota Surabaya, Kabupaten Gresik dan Kabupaten Bangkalan

\begin{tabular}{|c|c|c|c|c|}
\hline \multirow{2}{*}{$\begin{array}{c}\text { Alternatif } \\
\text { Terkait } \\
\text { Sengketa } \\
\text { Pulau } \\
\text { Galang }\end{array}$} & \multirow{2}{*}{$\begin{array}{c}\text { Wilayah } \\
\text { Kabupaten } \\
\text { Kota }\end{array}$} & \multicolumn{3}{|c|}{$\begin{array}{c}\text { Luas Wilayah Bagi Hasil Kelautan Termina } \\
\text { Teluk Lamong }\end{array}$} \\
\hline & & $\begin{array}{c}\text { Berdasar UU } \\
32 / 2004\end{array}$ & $\begin{array}{c}\text { Berdasar UU } \\
23 / 2014\end{array}$ & $\begin{array}{c}\text { Wilayah } \\
\text { Pertampalan } \\
\text { Klaim }\end{array}$ \\
\hline \multirow{3}{*}{$\begin{array}{c}\text { Jika } \\
\text { dianggap } \\
\text { Tidak Ada }\end{array}$} & $\begin{array}{c}\text { Kota } \\
\text { Surabaya }\end{array}$ & 60,404 ha & 34,386 ha & \multirow[b]{2}{*}{ $\pm 26,018 \mathrm{ha}$} \\
\hline & $\begin{array}{c}\text { Kabupaten } \\
\text { Gresik }\end{array}$ & 14,222 ha & 40,240 ha & \\
\hline & $\begin{array}{c}\text { Kabupaten } \\
\text { Bangkalan }\end{array}$ & - & - & - \\
\hline
\end{tabular}




\begin{tabular}{|c|c|c|c|c|}
\hline \multirow{3}{*}{$\begin{array}{c}\text { Jika Masuk } \\
\text { Kota } \\
\text { Surabaya }\end{array}$} & $\begin{array}{c}\text { Kota } \\
\text { Surabaya }\end{array}$ & 67,141 ha & 46,700 ha & \multirow{2}{*}{ $\pm 20,441$ ha } \\
\hline & $\begin{array}{c}\text { Kabupaten } \\
\text { Gresik }\end{array}$ & 7,485 ha & 27,927 ha & \\
\hline & $\begin{array}{l}\text { Kabupaten } \\
\text { Bangkalan }\end{array}$ & - & - & \multirow{3}{*}{ $\pm 11,291$ ha } \\
\hline \multirow{3}{*}{$\begin{array}{c}\text { Jika Masuk } \\
\text { Kabupaten } \\
\text { Gresik }\end{array}$} & $\begin{array}{c}\text { Kota } \\
\text { Surabaya }\end{array}$ & 27,673 ha & 16,382 ha & \\
\hline & $\begin{array}{c}\text { Kabupaten } \\
\text { Gresik }\end{array}$ & 46,953 ha & 58,244 ha & \\
\hline & $\begin{array}{l}\text { Kabupaten } \\
\text { Bangkalan }\end{array}$ & - & - & - \\
\hline
\end{tabular}

\section{KESIMPULAN}

Kesimpulan yang dapat diambil dari penelitian ini adalah sebagai berikut.

1. Wilayah yang memperoleh bagi hasil kelautan Terminal Teluk Lamong adalah hanya Kota Surabaya dan Kabupaten Gresik.

2. Perubahan UU 32/2004 menjadi UU 23/2014 menghasilkan perubahan luas wilayah bagi hasil kelautan Terminal Teluk Lamong antara Kota Surabaya dan Kabupaten Gresik.

- Perubahan luas wilayah bagi hasil kelautan Terminal Teluk Lamong terbesar yaitu 26,018 Ha pada alternatif jika Pulau Galang dianggap tidak ada. Pembagian luas wilayah bagi hasil kelautan Kota Surabaya menjadi 34,386 Ha dan Kabupaten Gresik menjadi 40,240 Ha berdasarkan UU 23/2014.

- Perubahan luas wilayah bagi hasil kelautan Terminal Teluk Lamong terkecil yaitu 11,291 Ha pada alternatif jika Pulau Galang masuk Kabupaten Gresik. Pembagian luas wilayah bagi hasil kelautan Kota Surabaya menjadi 16,382 Ha dan Kabupaten Gresik menjadi 58,244 Ha berdasarkan UU 23/2014.

\section{UCAPAN TERIMA KASIH}

Penulis M.A. mengucapkan terima kasih kepada Badan Informasi Geospasial (BIG) dan Lembaga Antariksa dan Penerbangan Nasional (LAPAN) atas kesediannya untuk mengizinkan penulis menggunakan data-data dalam penelitian ini.

\section{DAFTAR PUSTAKA}

[1] Kementerian Dalam Negeri. 2012 a. Peraturan Menteri Dalam Negeri Republik Indonesia Nomor 76 Tahun 2012 Tentang Pedoman Penegasan Batas Daerah. Jakarta.

[2] Widiastuty, Ria. 2014. Analisa Penetapan Batas Pengelolaan Laut Daerah Berdasarkan Peraturan Menteri Dalam Negeri Nomor 76 Tahun 2012 (Studi Kasus: Sengketa Pulau Galang Perbatasan Kota Surabaya dan Kabupaten Gresik). Surabaya: Jurusan Teknik Geomatika, Fakultas Teknik Sipil dan Perencanaan, Institut Teknologi Sepuluh Nopember.

[3] Republik Indonesia. 2004. Undang-Undang Republik Indonesia Nomor 32 Tahun 2004 Tentang Pemerintahan Daerah. Jakarta.

[4] Republik Indonesia. 2014. Undang-Undang Republik Indonesia Nomor 23 Tahun 2014 Tentang Pemerintahan Daerah. Jakarta.

[5] Kementerian Dalam Negeri. 2012 b. Lampiran Peraturan Menteri Dalam Negeri Republik Indonesia Nomor 76 Tahun 2012 Tentang Pedoman Penegasan Batas Daerah. Jakarta.

[6] Poerbandono., dan Djunarsjah, Eka. 2005. Survei Hidrografi. Bandung: PT. Refika Aditama. 